\title{
Notes on stinkhorns (Phallaceae) in the Western Ghats and West coast of India
}

\author{
N.C. Karun ${ }^{1}$ and K.R. Sridhar ${ }^{2,3, *}$ \\ ${ }^{1}$ Western Ghats Macrofungal Research Foundation, Bittangala, Virajpet 571 218, Kodagu, Karnataka, India \\ ${ }^{2}$ Department of Biosciences, Mangalore University, Mangalagangotri, Mangalore 574 199, Karnataka, India \\ ${ }^{3}$ Centre for Environmental Studies, Yenepoya University, Mangalore 575 018, Karnataka, India \\ Corresponding author Email:kandikere@gmail.com
}

(Submitted on September 20, 2019; Accepted on November 19, 2019)

\section{ABSTRACT}

The Western Ghats and west coast of India are known for several edible, medicinal and ectomycorrhizal fungi. During macrofungal expedition in the Western Ghats and southwest coast of Karnataka, several macrofungi belonging to the family Phallaceae were collected. This study embodies morphological description with key for seven species of Phallaceae belonging to five genera (Dictyophora cinnabarina, Ileodictyon gracile, Lysurus brahmagirii, Phallus atrovolvatus, P. duplicatus, P. merulinus and Simblum periphragmoides).

KEYWORDS: Macrofungi, Dictyophora, Ileodictyon, Lysurus, Phallus, Simblum

\section{INTRODUCTION}

Members belonging to the family Phallaceae (Phallales, Phallomycetidae, Agaricomycotina, Basidiomycota) have wide geographic distribution (tropical, subtropical and temperate) under varied climate and vegetation (e.g. grassland, bamboo and broad-leaved forests) (Li et al., 2016). The characteristic morphology of sporocarps of stinkhorns with spongy pseudostipe (white or light-orange or yellowish), specific odor (fetid), presence of sticky spore mass on bellshaped gleba or receptacle (differently ornamented), presence or absence of netted indusium and egg or volva usually possesses rhizomorphs (white or light-brown or dark-brown) which made their identification less complicated. Their early stages of development initiate with round or oval basidiocarp with bone-white to varied colors. Development takes place in a few hours and attain maturity, but the lifespan of their fruit bodies extends only for a few hours in a day. The Index Fungorum (2019) lists 52 records of Dictyophora (29 spp.), six records of Ileodictyon (3 spp.), 177 records of Phallus (108 spp.), 45 records of Lysurus (33 spp.) and 26 records of Simblum (14 spp.).

Some literature is available on the members of Phallaceae distributed in different parts of the Indian Subcontinent (e.g. Assam, Himachal Pradesh, Jammu \& Kashmir, Karnataka, Kerala, Maharashtra, Orissa, Punjab, Tamil Nadu, Uttar Pradesh and West Bengal) (Tewaria and Khare, 1968; Abrar et al., 2007; Das et al., 2007; Dash et al., 2010; Mohanan, 2011; Dutta et al., 2012; Soosairaj et al., 2012; Sridhar and Karun, 2013; Gogoi and Prakash, 2014, 2015; Kour et al., 2016). The Western Ghats and west coast region of India are also well known for different species belonging to Phallaceae (Abrar et al., 2007, 2012; Swapna et al., 2010; Mohanan, 2011; Sridhar and Karun, 2013; Karun and Sridhar, 2014, 2016; Greeshma et al., 2016; Karun et al., 2018). The present note provides brief description along with distribution and key for seven species belonging to five genera of Phallaceae (Dictyophora, Ileodictyon, Lysurus, Phallus and Simblum) found in the Western Ghats and southwest coastal region of Karnataka. The specimens have been deposited in the herbarium of Western Ghats Macrofungal Research Foundation (WGMRF), Bittangala, Virajpet, Kodagu District, Karnataka. General diagnostic characteristics of the members of
Phallaceae found in the Western Ghats and west coast of India are given in Table 1.

Table 1. General diagnostic characteristics of the members of Phallaceae found in the Western Ghats and west coast of India

\begin{tabular}{|c|c|c|c|c|c|}
\hline & $\begin{array}{l}\text { Basidiomata } \\
\text { (immature) }\end{array}$ & Pseudostipe & Indusium & \begin{tabular}{|l|}
$\begin{array}{l}\text { Gleba/Fertile } \\
\text { head }\end{array}$ \\
\end{tabular} & $\begin{array}{l}\text { Spore } \\
\text { color }\end{array}$ \\
\hline $\begin{array}{l}\text { Dictyophora } \\
\text { cinnabarina } \\
\text { (Fig. 1) }\end{array}$ & $\begin{array}{l}\text { Oval to pear- } \\
\text { shaped; } \\
\text { creamish- } \\
\text { brown with } \\
\text { rhizomorphs }\end{array}$ & $\begin{array}{l}\text { Honey- } \\
\text { combed; } \\
\text { pitted; light- } \\
\text { yellowish; } \\
\text { hollow }\end{array}$ & $\begin{array}{l}\text { Regular; } \\
\text { covers entire } \\
\text { fruit body; } \\
\text { orange; } \\
\text { hexagonally } \\
\text { porous }\end{array}$ & $\begin{array}{l}\text { Bell-shaped; } \\
\text { roughly } \\
\text { grooved; } \\
\text { perforated at } \\
\text { the centre }\end{array}$ & $\begin{array}{l}\text { Dark olive- } \\
\text { green }\end{array}$ \\
\hline $\begin{array}{l}\text { Ileodictyon } \\
\text { gracile } \\
\text { (Fig. 2) }\end{array}$ & $\begin{array}{l}\text { Spherical to } \\
\text { oval; } \\
\text { yellowish- } \\
\text { white } \\
\text { rhizomorphs }\end{array}$ & Inconspicuous & Not present & $\begin{array}{l}\text { Hollow } \\
\text { sphere to oval } \\
\text { net; } \\
\text { hexagonal } \\
\text { shallow cage- } \\
\text { like }\end{array}$ & $\begin{array}{l}\text { Glebifers } \\
\text { olive- } \\
\text { brown to } \\
\text { olive-green }\end{array}$ \\
\hline $\begin{array}{l}\text { Lysurus } \\
\text { bramagirii } \\
\text { (Fig. 3) }\end{array}$ & $\begin{array}{l}\text { Oval to pear } \\
\text { shaped; } \\
\text { brownish } \\
\text { with } \\
\text { rhizomorphs }\end{array}$ & $\begin{array}{l}\text { Ridged; } \\
\text { white; hollow }\end{array}$ & Not present & $\begin{array}{l}\text { 4-6 finger- } \\
\text { like arms; } \\
\text { greyish- } \\
\text { brown }\end{array}$ & $\begin{array}{l}\text { Dark- } \\
\text { brown }\end{array}$ \\
\hline $\begin{array}{l}\text { Phallus } \\
\text { astrovolvatus } \\
\text { (Fig. 4) }\end{array}$ & $\begin{array}{l}\text { Sub-glonose } \\
\text { to oval to } \\
\text { irregular; } \\
\text { greyish- } \\
\text { brown with } \\
\text { rhizomorphs }\end{array}$ & $\begin{array}{l}\text { Spongy; } \\
\text { white; } \\
\text { hollow }\end{array}$ & $\begin{array}{l}\text { Irregular; } \\
\text { covers one- } \\
\text { third of } \\
\text { stipe; white; } \\
\text { pentagonally } \\
\text { porous }\end{array}$ & $\begin{array}{l}\text { Bell-shaped; } \\
\text { smooth to } \\
\text { finely } \\
\text { grooved; } \\
\text { perforated }\end{array}$ & $\begin{array}{l}\text { Dark- } \\
\text { brown }\end{array}$ \\
\hline $\begin{array}{l}\text { Phallus } \\
\text { duplicatus } \\
\text { (Fig. 5) }\end{array}$ & $\begin{array}{l}\text { Sub-globose } \\
\text { to oval; } \\
\text { brown; finely } \\
\text { granular with } \\
\text { rhizomorphs }\end{array}$ & $\begin{array}{l}\text { Spongy; } \\
\text { honey- } \\
\text { combed; } \\
\text { white; hollow }\end{array}$ & $\begin{array}{l}\text { Irregular; } \\
\text { covers half } \\
\text { of stipe; } \\
\text { white; } \\
\text { pentagonally } \\
\text { porous }\end{array}$ & $\begin{array}{l}\text { Conical to } \\
\text { campanulate; } \\
\text { irregular } \\
\text { surface; } \\
\text { apical disc } \\
\text { perforated }\end{array}$ & Pale-brown \\
\hline $\begin{array}{l}\text { Phallus } \\
\text { merulinus } \\
\text { (Fig. 6) }\end{array}$ & $\begin{array}{l}\text { Sub-globose } \\
\text { to oval; ash- } \\
\text { brown; } \\
\text { Smooth to } \\
\text { irregular with } \\
\text { rhizomorphs }\end{array}$ & $\begin{array}{l}\text { Spongy; } \\
\text { honey- } \\
\text { combed; } \\
\text { white; hollow }\end{array}$ & $\begin{array}{l}\text { Regular; } \\
\text { covers two- } \\
\text { third of } \\
\text { stipe; white; } \\
\text { penta- or } \\
\text { hexagonally } \\
\text { porous }\end{array}$ & $\begin{array}{l}\text { Bell-shaped; } \\
\text { smooth to } \\
\text { irregular; } \\
\text { apical disc } \\
\text { perforated }\end{array}$ & $\begin{array}{l}\text { Olive- } \\
\text { brown }\end{array}$ \\
\hline $\begin{array}{l}\text { Simblum } \\
\text { periphragmoides } \\
\text { (Fig. 7) }\end{array}$ & $\begin{array}{l}\text { Sub-globose } \\
\text { to oval; } \\
\text { Creamish- } \\
\text { orange; } \\
\text { smooth with } \\
\text { rhizomorphs }\end{array}$ & $\begin{array}{l}\text { Spongy; } \\
\text { honey- } \\
\text { combed; } \\
\text { creamish; } \\
\text { hollow }\end{array}$ & Not present & $\begin{array}{l}\text { Hollow } \\
\text { sphere to oval } \\
\text { lattice; } \\
\text { pentagonal } \\
\text { deep ridges }\end{array}$ & $\begin{array}{l}\text { Greyish- } \\
\text { brown }\end{array}$ \\
\hline
\end{tabular}

\section{TAXONOMIC DESCRIPTIONS}

1. Dictyophora cinnabarina (W.S. Lee) Kreisel, Czech Mycol.48(4): 278, 1996.

Fig. 1

Phallic extrusion occurs from a partially submerged egg with a whitish pseudostipe immersed in volval matrix and surmounted by a fertile head covered with dark- to olive-green foul-smelling slimy gleba and bright- or dull-orange indusium flaring from beneath the fertile head as long skirt to cover the whole fruit body. Taste and odor not distinctive and inedible. 


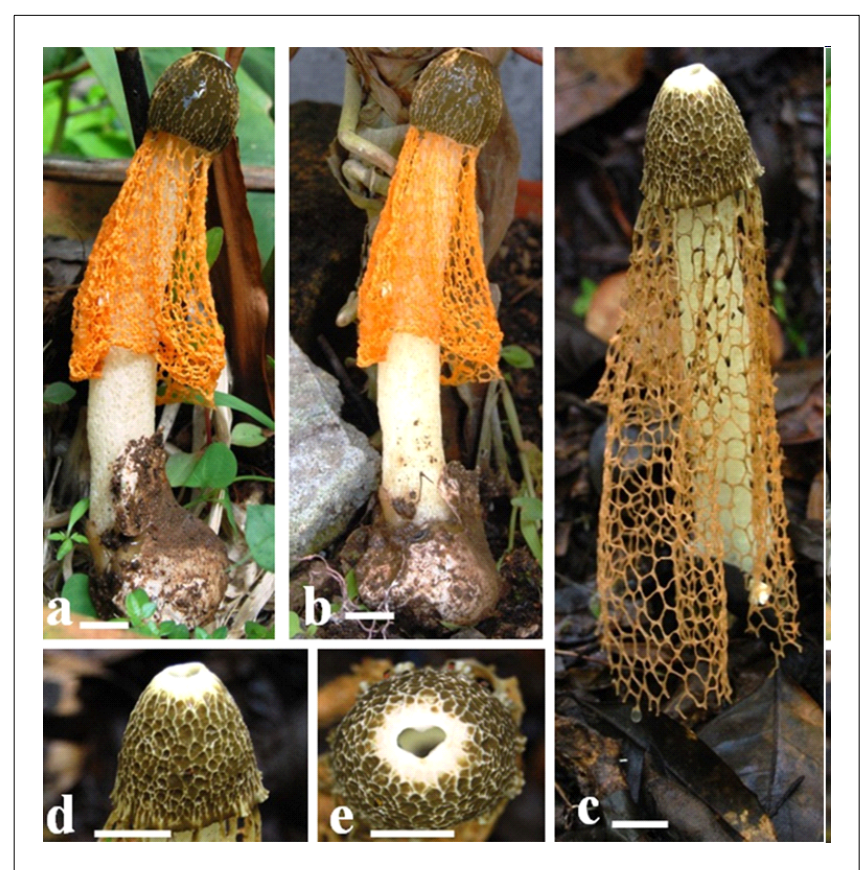

Fig. 1. Dictyophora cinnabarina: Developing stages $(\mathbf{a}, \mathbf{b})$ and mature (c) fruit body with side view (d) and top view (e) of gleba (Scale bar, $1 \mathrm{~cm})$.

Immature basidiomata hypogeous, sub-globose to oval- to pear-shaped $(3.5-4.0 \times 3.5-4.5 \mathrm{~cm})$ smooth, consisting of resistant thin rubbery to elastic membranous white to creamish-brown exoperidium enclosing thick gelatinous hyaline mesoperidium $(3.0-3.4 \mathrm{~mm})$ separated from the embryonic spore mass and pseudostipe by an endoperidium; attached to below-ground mycelial cord in soil or roots through 2-5 conspicuous white rhizomorphs.

Basidiomata becomes epigeous or partially submerged, pseudostipe whitish, spongy, cylindrical (12.9-13.3 cm tall), honey-combed, hollow-pitted, fragile, tapering towards the apex $(1.6-1.7 \mathrm{~cm})$, broad at the base $(3.5-3.8 \mathrm{~cm})$ immersed in gelatinous volval matrix. The gleba at first smooth, bellshaped, slimy with mucous whitish deposits, with age becomes creamish-grey to greyish-yellow $(2.2-2.3 \times 2.2-2.5$ $\mathrm{cm})$, bears reticulate mesh of raised ribs, strongly chambered with apical disk perforated at the centre and flooded with oozing mucilaginous sticky stinky dark olive-green liquid. Indusium emerges out from the edge of the cap, orange, hexagonally porous net-like semi-elastic frill to cover full length of fruit body. Basidiospores cylindrical-ellipsoid, hyaline and smooth $(2.6-3.9 \times 1.1-1.7 \mu \mathrm{m})$.

Collections examined: India, Karnataka, Kodagu: Sampaje reserve forest, Namera C. Karun (DcS-WGMRF), June 25, 2012, Namera C. Karun; Virajpet coffee agroforest, Namera C. Karun (DcS-WGMRF), July 07, 2012

Remarks: Dictyophora cinnabarina is rare, solitary on soil under the canopy of tree species Lagerstroemia microcarpa and Spathodea campanulata. Identified based on the description by Mohanan (2011) from Kerala, Abrar et al. (2007) from Karnataka and Gogoi and Prakash (2014) from Assam.
2. Ileodictyon gracile Berk., London J. Bot. 4: 69, 1845.

Fig. 2

A hollow white net-like sub-spherical extrusion from an epigeous egg with 46 olive-green glebifers studded on the inner surface of the arms of the lattice. Taste and odor not distinctive and inedible.

Immature basidiomata epigeous, spherical to oval (0.4-0.6 $\times$ 0.4-0.7 cm), finely granular to smooth, consisting of resistant thin elastic membranous pinkish-orange to whitish-cream exoperidium enclosing thick gelatinous hyaline mesoperidium $(0.5-0.7 \mathrm{~mm})$ separated from the embryonic spore mass by an endoperidium. Basidiomata attached to wood/twigs or humus through conspicuous small 2-5 yellowish-white rhizomorphs. On maturity the basidiomata ruptures, exoperidium cracks to extrude a cage-like enclosure and the gleba/spore mass is carried upward on a lattice-like receptacle $(1.2-1.4 \times 1.6-2.5 \mathrm{~cm})$, whitish, composed of 5-8 delicate arms anastomosed to form a net-like clathrate sphere, irregular hexagonally porous, tubular, brittle and immersed below in the volval matrix. Gleba is small olivaceous mass, glebifers, olive-brown to olive-green, thick, gelatinous, deliquescent, 46 in number and studded on the inner surface of the arms of the lattice. Basidiospores ellipsoidal, hyaline and smooth $(3.1-3.7 \times 1.3-2.1 \mu \mathrm{m})$.

Collections Examined: India, Karnataka, Kodagu: Virajpet coffee agroforest, Namera C. Karun (IgV-WGMRF), July 09, 2012; Kadnur sacred grove, Namera C. Karun (IgVWGMRF), June 15, 2013; Dakshina Kannada: Konaje scrub jungles, Namera C. Karun (IgV-WGMRF), July 09, 2016, August 31, 2016.

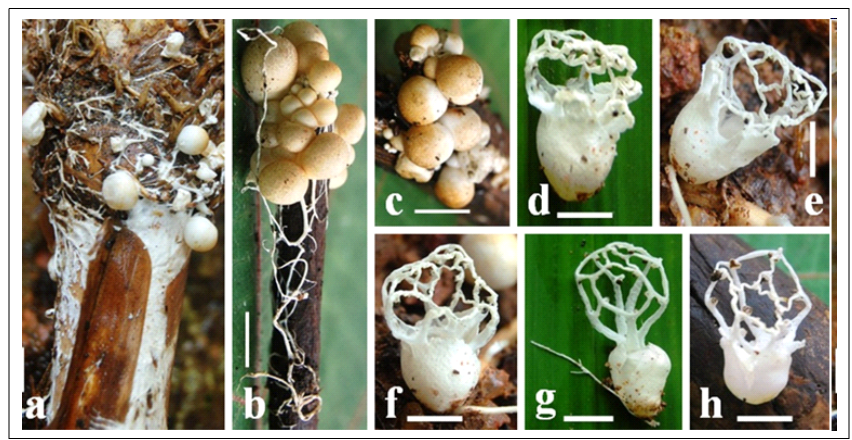

Fig.2. Ileodictyon gracile : Mycelial mat with initiation of basidiocarp (a) and developing basidiocarps $(\mathbf{b}, \mathbf{c})$ with different shapes of mature fruit bodies $(\mathbf{d}-\mathbf{h})($ Scale bar, $1 \mathrm{~cm})$.

Remarks: Ileodictyon gracile is frequent in small groups, humicolous and lignicolous on the bamboo culms (Burmania bamboosa). Identified based on the description by Mohanan (2011) from Kerala.

\section{Lysurus brahmagirii C. Mohanan, KFRI Handbook} (Peechi) 27: 364, 2011.

Fig. 3

Phallic extrusion from a partially-submerged egg with a whitish pseudostipe immersed in volval matrix and surmounted by fertile folded finger-like conical head covered with dark-brown foul-smelling slime. No distinct taste or odor and inedible. 


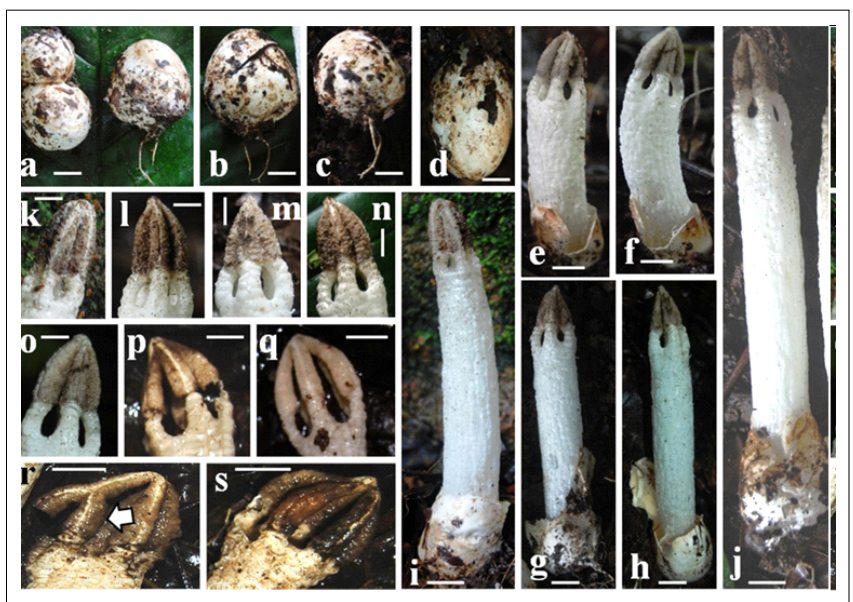

Fig.3. Lysurus brahmagirii: Immature basidiocarps (a-c) (note the extended rhizomorphs), developing fruit bodies (d-f) and mature fruit bodies (g-j) with different features of gleba (k-s) (note basal branch fusion of one of the arms in r) (Scale bar, $1 \mathrm{~cm}$ ).

Immature basidiomata hypogeous or partly submerged, subglobose to oval- to pear-shaped, $(2.6-3.6 \times 2.8-4.2 \mathrm{~cm})$, brownish, smooth, consisting resistant thin rubbery to elastic membranous white exoperidium enclosing gelatinous hyaline mesoperidium (3.5-3.8 $\mathrm{mm}$ ) separated from the embryonic spore mass and pseudostipe by an endoperidium. Attached to soil through conspicuous 2-5 whitish rhizomorphs.

Basidiomata becomes epigeous, pseudostipe whitish, spongy, cylindrical, (8.5-14.5 $\mathrm{cm}$ tall) grooved and ridged, distantly hollow-pitted, fragile, tapering towards the apex $(1.5-1.8 \mathrm{~cm})$, broad at the base $(2.5-2.9 \mathrm{~cm})$, immersed in volval matrix. The head at first finely granular, 4-6 vertical fertile greyishbrown to ash-brown arms $(1.8-2.2 \times 2.3-2.6 \mathrm{~cm})$ connected to pseudostipe through white sterile arm-like connecting extensions $(0.3-0.5 \times 0.5-0.8 \mathrm{~cm})$, arms folded to form a conical structure (opens at later stage), constricted at the top with a deep central longitudinal groove running along the surface of each arm, bears a reticulate mesh of raised ribs, spread with oozing mucilaginous sticky stinky dark-brown liquid. On ageing after the emergence of spores, the fertile arms get detached and open up at the apex with wrinkled to granular surface becoming pale. Basidiospores cylindricalellipsoid, hyaline and smooth $(3.4-5.2 \times 1.3-2.1 \mu \mathrm{m})$.

Collections Examined: India, Karnataka, Kodagu: Virajpet coffee agroforest, Namera C. Karun (LbBS-WGMRF), August 08, 2012 and July 07, 2013; B'Shettigeri coffee agroforest, Namera C. Karun(LbBS-WGMRF), July 29, 2015.

Remarks: Lysurus brahmagirii is rare, solitary or gregarious on humus or soil under the canopy of tree species Mangifera indica and Syzygium cumini. Identified based on description of Lysurus brahmagirii by Mohanan (2011) from Kerala, description of Lysurus cruciatus by Abrar et al. (2012) from Karnataka and description of Lysurus sphaerocephaum by Caffot et al. (2018) from Argentina.

4. Phallus atrovolvatus Kreisel \& Calonge, Boln Soc. Micol. Mdrrid 29: 6, 2005.

Fig. 4

Phallic extrusion from partially submerged egg with whitish pseudostipe immersed in volval matrix and surmounted by a fertile head covered with dark-brown foul-smelling slime and white short irregular to restricted autodigestable indusium flaring from beneath the head as short skirt. No distinctive taste or odor and inedible.

Immature basidiomata partially hypogeous or submerged, sub-globose to oval $(4.0-4.5 \times 4.2-4.8 \mathrm{~cm})$, tall to irregular $(2.0-3.5 \times 2.0-3.8 \mathrm{~cm})$, smooth to finely granular, consisting of resistant thin rubbery to elastic membranous creamishbrown to creamish-grey to greyish-brown exoperidium enclosing gelatinous hyaline mesoperidium $(2.5-3.0 \mathrm{~mm}$ thick) separated from the embryonic spore mass and pseudostipe by an endoperidium. Attached to soil through conspicuous 2-5 white to brown rhizomorphs. Basidiomata becomes epigeous, pseudostipe whitish, spongy, hollowpitted, cylindrical (8.9-14.5 cm tall), fragile, tapering towards the apex (2.6-2.8), broad at the base $(3.8-4.2 \mathrm{~cm})$ immersed in gelatinous volval matrix. The gleba at first smooth, campanulate, slimy and with mucoid whitish deposits, with age becomes finely grooved and ridged (3.6-4.1 $\times 3.8-4.2$ $\mathrm{cm}$ ), with apical disk perforated at the centre and finally spread out with oozing mucilaginous sticky stinky darkbrown liquid. White indusium flares beneath the head as short skirt $(5.5-6.4 \times 3.9-5.8 \mathrm{~cm})$ covers one-third of stipe, pentagonally to irregularly porous, net-like, disintegrates to irregular net. Basidiospores cylindrical-ellipsoid, hyaline and $\operatorname{smooth}(2.6-3.3 \times 1.0-1.3 \mu \mathrm{m})$.

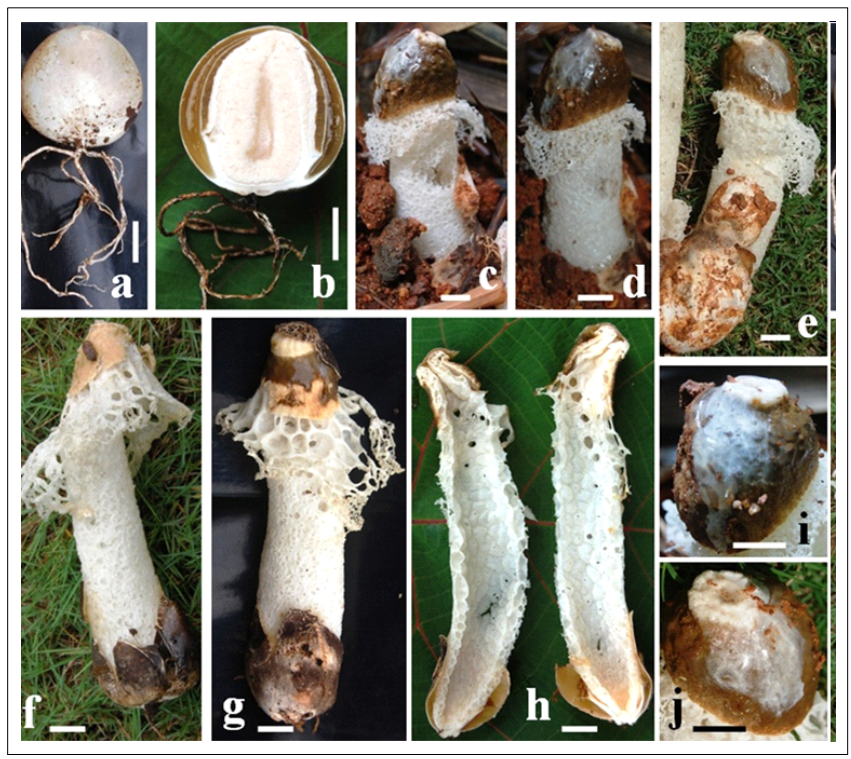

Fig.4. Phallus atrovolvatus: Immature badiocarp with rhizomorphs (a), vertical section of basidiocarp (b), developing stages of fruit bodies (c-e), mature fruit bodies $(\mathbf{f}, \mathbf{g})$ and vertical section of stipe (h) with details of gleba $(\mathbf{i}, \mathbf{j})($ Scale bar, $1 \mathrm{~cm})$.

Collections Examined: India, Karnataka, Dakshina Kannada: Konaje scrub jungles, Namera C. Karun (PaSJWGMRF), July 07, 2014 and June 06, 2016.

Remarks: Phallus atrovolvatus is rare, solitary or in small groups on soil beneath the canopy of Burmania bamboosa, Caryota urens and Cocos nucifera. Identified based on 
description by Gogoi and Prakash (2014) from Assam and key by Medeiros et al. (2017).

\section{Phallus duplicatus Bosc., Mag. Gesell. naturf. Freunde,} Berlin 5: 86, 1811.

Fig. 5

Phallic extrusion from a partially-submerged egg with a whitish pseudostipe immersed in volval matrix and surmounted by a fertile head covered with pale brown foulsmelling slime and white autodigestable net-like indusium flaring from beneath the head to cover up to mid-stipe region. Inedible, rare without distinct taste and odor.

Immature basidiomata hypogeous or partly submerged, subglobose to oval $(3.0-3.2 \times 3.4-3.6 \mathrm{~cm})$ smooth to finely granular, consisting of resistant thin rubbery to elastic membranous brown exoperidium enclosing gelatinous hyaline mesoperidium (2.5-3 $\mathrm{mm}$ thick) separated from the embryonic spore mass and pseudostipe by an endoperidium. Attached to soil through 25 white conspicuous rhizomorphs. Basidiomata becomes epigeous, pseudostipe whitish, spongy, cylindrical (12.1-14.2 cm tall), honey-combed to hollowpitted, fragile, tapering towards the apex $(1.8-2.3 \mathrm{~cm})$, broad at the base $(2.6-2.8 \mathrm{~cm})$ immersed in gelatinous volval matrix. The gleba at first smooth, conical to campanulate, slimy with whitish mucous deposits. On maturity $(2.3-2.8 \times 2.2-2.5 \mathrm{~cm})$, bears a fine mesh of raised ribs, grooved and ridged with apical disk perforated at the centre and finally spread with oozing mucilaginous sticky stinky pale-brown liquid. Indusium emerges out from the lower margin of the cap where pseudostipe merges $(5.8-7.6 \times 6.2-6.9 \mathrm{~cm})$, white, irregular to pentagonally porous, net-like, covers up to mid-region of pseudostipe, disintegrates or autodigests at the lower margin. Basidiospores cylindrical to ellipsoid, hyaline and smooth (3.4-3.9 $\times 1.3-1.5 \mu \mathrm{m})$.
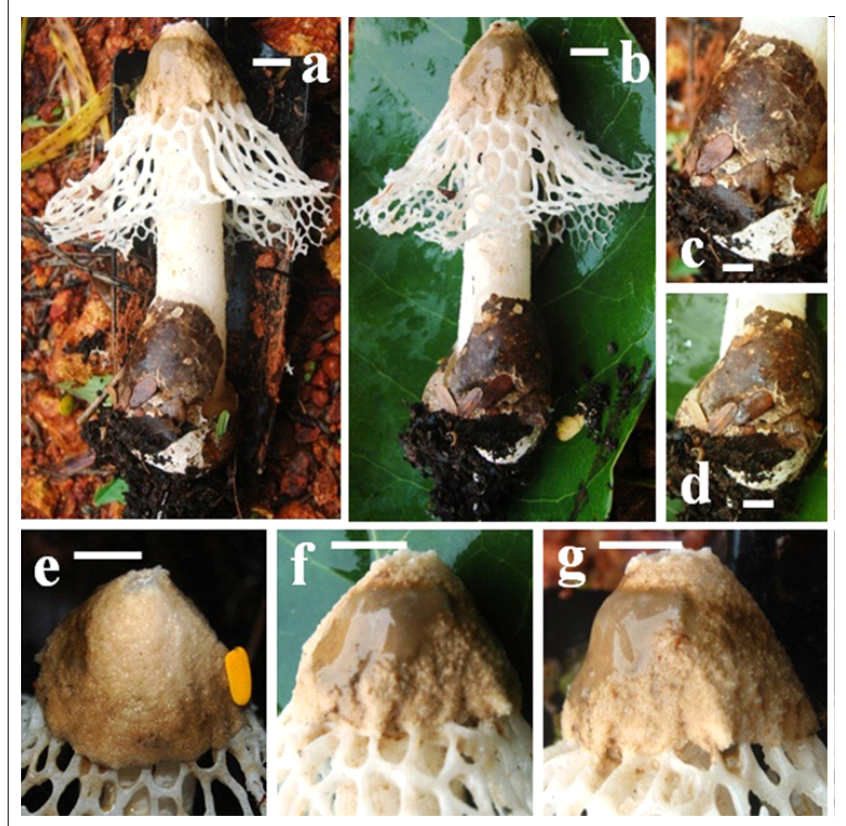

Fig.5. Phallus duplicatus : Developed fruit bodies $(\mathbf{a}, \mathbf{b})$, nature of volva $(\mathbf{c}, \mathbf{d})$ with details of gleba $(\mathbf{e}-\mathbf{g})($ Scale bar, $1 \mathrm{~cm})$.
Collections Examined: India, Karnataka, Dakshina Kannada: Konaje scrub jungles, Namera C. Karun (PdSJWGMRF), June 06, 2013 and June 06, 2016.

Remarks: Phallus duplicatus is solitary in soil occurring beneath Cocos nucifera and Musa paradisiaca. Identified based on description by Gogoi and Prakash (2014) from Assam and description with key by Trierveiler-Pereira et al. (2019) from Brazil.

\section{Phallus merulinus (Berk.) Cooke, Grevillea 11 (58): 57 1882 . \\ Fig. 6}

Phallic extrusion from a partially submerged egg with whitish pseudostipe immersed in volval matrix and surmounted by a fertile head covered with dark to olive-brown foul-smelling slime and white net-like indusium flaring from beneath the head as medium skirt. No distinctive taste or odor and inedible.

Immature basidiomata hypogeous, sub-globose to oval to pear-shaped $(3.5-4.4 \times 4.5-5.3 \mathrm{~cm})$, smooth to finely granular, consisting of resistant thin rubbery to elastic membranous greyish-brown to ash-brown exoperidium enclosing gelatinous hyaline mesoperidium (3.0-3.3 $\mathrm{mm}$ thick) separated from the embryonic spore mass and pseudostipe by an endoperidium. Attached to soil or roots through conspicuous 2-5 white rhizomorphs.

Basidiomata epigeous or partially epigeous, pseudostipe white, spongy, cylindrical (14.5-15.2 cm tall) honeycombed to hollow-pitted, fragile, tapers towards the apex $(1.7-1.9 \mathrm{~cm})$, broadens at the base $(3.8-4.2 \mathrm{~cm})$ immersed in gelatinous volval matrix. The gleba at first smooth, bellshaped, slimy with whitish mucous deposits, with age bears a reticulate mesh of raised ribs, strongly chambered with apical disk perforated at the centre finally flooded with oozing out mucilaginous sticky stinky dark- to olive-brown

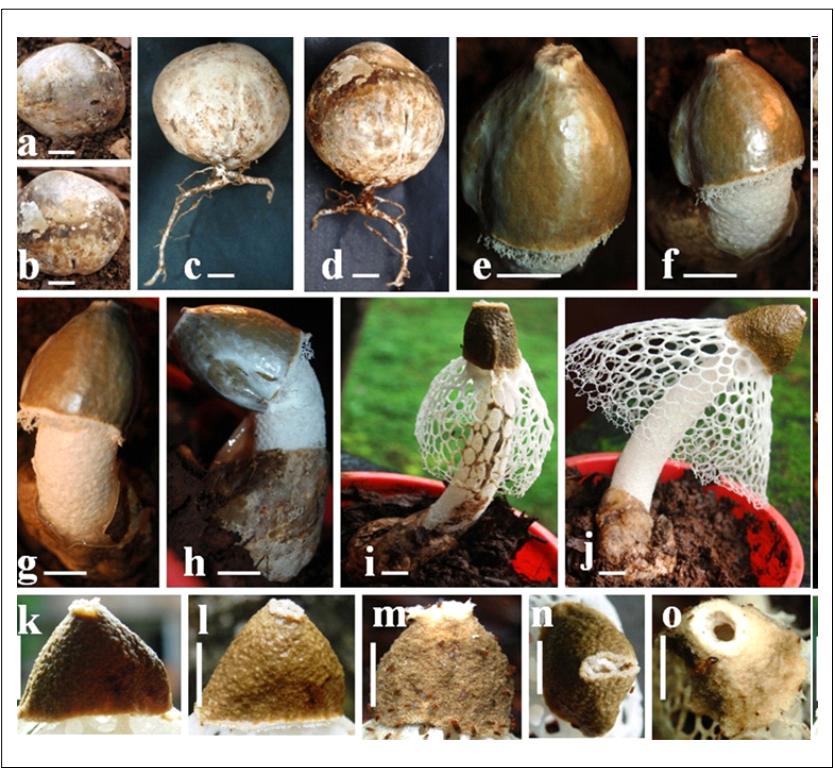

Fig. 6. Phallus merulinus : Immature basidiocarps (a, d) (note the extended rhizomorphs in $\mathbf{c}$ and $\mathbf{d}$ ), developing stages of fruit bodies $(\mathbf{e}-\mathbf{h})$ and mature fruit bodies $(\mathbf{i}, \mathbf{j})$ with details of gleba (k-o) (Scale bar, $1 \mathrm{~cm}$ ). 
liquid (2.2-2.4 $\times 3.6-3.8 \mathrm{~cm})$. Indusium emerges out from the base of the cap, white, pentagonally and hexagonally porous (larger at top than below) net-like flaring, frilled and develops up to two-third of the pseudostipe. Basidiospores cylindrical-ellipsoid, hyaline and smooth (3.1-3.9 × 1.0$1.5 \mu \mathrm{m})$.

Collections Examined: India, Karnataka, Dakshina Kannada: Konaje scrub jungles, Namera C. Karun (PmSJWGMRF), June 23, 2013 and July 18, 2014.

Remarks: Phallus merulinus is solitary or in small groups on soil underneath Cocos nucifera, Musa paradisiaca and wild banana. Identified based on description by Gogoi and Prakash (2014) from Assam, description by Sridhar and Karun (2013) from Karnataka and description with key by TrierveilerPereira et al. (2019) from Brazil.

\section{Simblum periphragmoides Klotzsch, Lich. Nov. Zeland.} 2: 164, 1831 .

Fig. 7

Phallic extrusion from a partially submerged egg with a creamish-white pseudostipe immersed in volval matrix and surmounted by a fertile hollow lattice-like spherical head covered with greyish-brown foul-smelling slime. No distinctive taste or odor and inedible.

Immature basidiomata hypogeous, sub-globose to ovalshaped (3.0-4.0 × 3.5-4.2 cm) smooth, consisting of resistant thin rubbery to elastic membranous creamish-white to creamish-orange exoperidium enclosing thick, gelatinous, hyaline, mesoperidium $(3.0-3.5 \mathrm{~mm})$ separated from the embryonic spore mass and pseudostipe by an endoperidium. Attached to the soil or roots through white conspicuous 25 rhizomorphs.

Basidiomata becomes epigeous, pseudostipe creamish, spongy, cylindrical $(7.5-12 \times 2.5-3.1 \mathrm{~cm})$, equal, distantly hollow-pitted to honey-combed immersed in gelatinous volval matrix. The head at first creamish, smooth, circular to oval, bears a reticulate mesh of hollow-pitted to pentagonally porous $(0.4-0.6 \mathrm{~cm})$ on anastomosed arms, on maturity

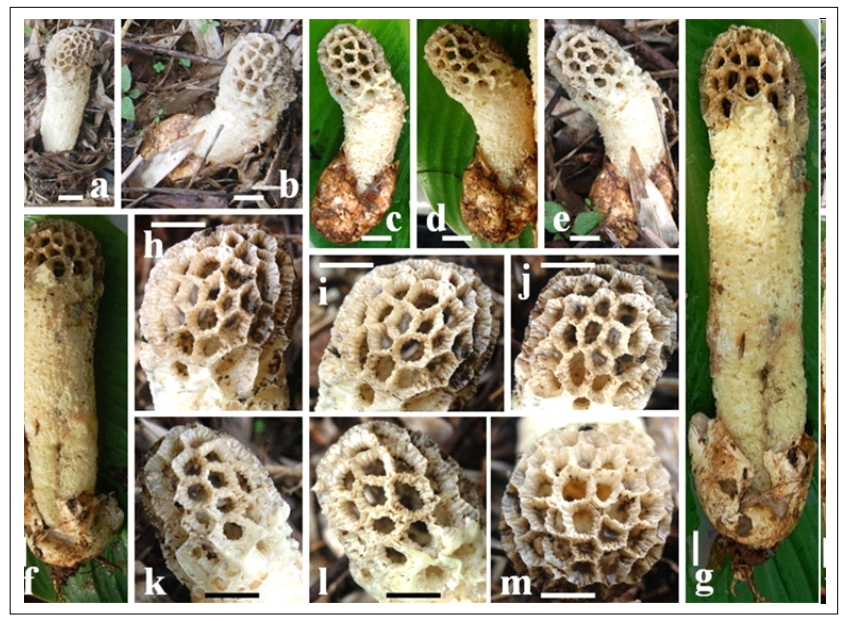

Fig. 7. Simblum periphragmoides: Developing stages of fruit bodies (a-e), mature fruit bodies (f, $\mathbf{g}$ ) with lattice-like fertile head $(\mathbf{h}-\mathbf{m})($ Scale bar, $1 \mathrm{~cm})$. becomes greyish-brown to ash-brown net-like raised with ribs compactly connected to one another forming a cage-like hollow sphere $(2.6-3.2 \times 2.3-2.8 \mathrm{~cm})$ connected to pesudostipe by arm-like extensions $(0.3-0.5 \mathrm{~cm})$. Surface grooved and ridged and with age spread out with oozing mucilaginous sticky stinky greyish-brown liquid. With age after the release of spores, the raised ribs become shrink with wrinkles. Basidiospores are ellipsoidal, hyaline and smooth $(3.7-4.9 \times 1.8-2.4 \mu \mathrm{m})$.

Collections Examined: India, Karnataka, Kodagu: B'Shettigeri underneath bamboo thickets, Namera C. Karun (SpBS-WGMRF), July 08, 2016.

Remarks: Simblum periphragmoides is rare, solitary or in small groups on soil underneath the wild bamboo (Bambusa). Identified based on description of Lysurus periphragmoides by Acharya et al. (2010) from West Bengal and description of $L$. sphaerocephaum by Caffot et al. (2018) from Argentina.

\section{Identification Key}

1. Basidiomata with fertile head, pseudostipe with volva and indusium

2. Basidiomata with fertile head, pseudostipe with volva and without indusium 7

3. Basidiomata without fertile head, pseudostipe and indusium.

8

4. (a) Indusium white ………………........................... 5

(b) Indusium colored ................................................. 6

5. (a) Indusium long skirt-like, bulged/frilled and exhibits at least two-third of the length of pseudostipe above the volval matrix with olive-brown foul smelling slime deposits on. .Phallus merulinus

(b) Indusium medium knee-skirt-like, bulged/frilled and covers half the length of pseudostipe above the volval matrix with pale-brown foul smelling slime deposits on head ......................... Phallus duplicatus

(c) Indusium short mini-skirt-like, delimited/fringed and exhibits one-third the length of pseudostipe above the volval matrix with dark-brown foul smelling slime deposits on head ....................Phallus atrovolvatus

6. Orange indusium, long skirt-like, bulged/frilled and covers full length of fruit body with dark olive-green foul smelling slime deposits on head. ... Dictyophora cinnabarina

7. (a) Basidiomata with fertile folded fingers-like conical head covered with dark-brown foul smelling slime... ..Lysurus brahmagirii

(b) Basidiomata with fertile hollow lattice-like spherical to oval head covered with greyish-brown foul smelling slime .........Simblum periphragmoides

8. Basidiomata with a sterile, irregular hexagonally porous, sub-spherical lattice or net-like receptacle 
emerging from egg with fertile olive-brown to olivegreen glebifers studded on the inner surface of the arms of the lattice Ileodictyon gracile

\section{DISCUSSION}

Being distinguished hotspot of biodiversity, occurrence of diverse macrofungi in the Western Ghats and its surrounds is not surprising. Significance to study phalloid fungi is manifold owing to their diverse morphology, edibility and medicinal potential. Stinkhorns belong to Dictyophora and Phallus which are historically known for their nutritional and medicinal value (Lin et al., 2011). In China, six species of Dictyophora and three species of Phallus have been listed as edible fungi (Dai et al., 2010). However, Li et al. (2016) listed two species of Dictyophora as edible as well as medicinal in China, while five and three Phallus spp. as edible and medicinal, respectively. Owing to the overlapping characteristics, Dring (1964) suggested to merge the genus Dictyophora with that of Phallus and there is a dilemma to understand the taxonomy of these genera solely on morphological grounds (Li et al., 2014). This view has been supported by the morphological and molecular studies that the presence or absence of indusium could not be the criteria to distinguish the genera of Phallaceae and thus the genus Dictyophora has been considered as synonym of Phallus (Cabral et al., 2012; Liet al., 2014; Song et al., 2018).

Several species belonging to Lysurus have been reported from India, viz. Lysurus borealis (Burt) Henn. (Himachal Pradesh), L. brahmagirii C. Mohanan (Kerala), L. cruciatus (Lepr. \& Mont.) Henn., L. gardneri Berk. (Karnataka), L. habungianus G. Gogoi \& Prakash (Assam) L. periphragmoides (Uttar Pradesh and West Bengal) and L. sulcatus (Cooke \& Massee) G. Cunn. (Maharashtra) (Narasimhan, 1932; Ahmed, 1940; Tewaria and Khare, 1968; Patil, 1978; Agarwal et al., 1984; Acharya et al., 2010; Mohanan, 2011; Abrar et al., 2012). There are glaring morphological differences in fruit bodies between the genera Lysurus and Simblum especially the apex of the pseudostipe, i.e. finger- and lattice-like fertile regions, respectively. Simblum periphragmoides Klotzsch (from Punjab) and $S$. sphaerocephalum Schlecht (from Uttar Pradesh) (Ahmad, 1940; Tewaria and Khare, 1968) have been considered as synonyms of Lysurus periphragmoides Klotzsch (Gogoi and Prakash, 2015). Subsequently, species with sporophores similar to Simblum spp. have been reported as Lysurus spp. (Acharya et al., 2010; Gogoi and Prakash, 2015). However, the Index Fungorum retains 26 records of Simblum (14 spp.) including Simblum periphragmoides. The Lysurus sphaerocephaum differs from that of $S$. periphragmoides in shape of volva, striations on stipe and net morphology of fertile region (Caffot et al., 2018). Unlike regular pentagonal deep-netted $S$. periphragmoides, the fertile region of L. sphaerocephaum is shallow irregular net, thus it almost resembles the surface features of finger-like projections of fertile region of L. brahmagirii. Based on comparison of surface features of fertile part of Lysurus and Simblum, it is likely that $L$. sphaerocephaum is an intermediary stage, which has been separated from so-called L. periphragmoides based on molecular investigations by Caffot et al. (2018). In our study, in some collections of $L$. brahmagirii showed fusion of finger-like projections at the base of fertile region (see Fig. 3r). Considering such fusion of terminal arms; presence of ridges and groves; greyish-brown arms, there are possibilities that Symblum has evolved from Lusurus with an intermediary stage as L. sphaerocephaum. Further focus using precise morphological and molecular tools (e.g. Gogoi and Prakash, 2015; Caffot et al., 2018) with different species and varieties from wide geographical region may reveal more about the morphological and phylogenic complexities between two genera of Lysurus and Simblum.

Three species of Phallales in this study (D. cinnabarina, $P$. merulinus and $S$. periphragmoides) seem to be putatively ectomycorrhizal with monocots and or dicots. Further insights are warranted to decipher their ectomycorrhizal association by field and laboratory studies. The Indian subcontinent being geographically and climatically diverse with different vegetation pattern, precise attention provide ample scope to explore various members of Plallaceae.

\section{ACKNOWLEDGEMENTS}

The authors are indebted to the reviewer and editor for constructive suggestions to improve the presentation of this manuscript. The corresponding author (KRS) is grateful to the University Grants Commission, New Delhi and Mangalore University for the award of UGC-BSR Faculty Fellowship and Adjunct Professorship, respectively.

\section{REFERENCES}

Abrar, S., Swapna, S. and Krishnappa, M. 2007. Dictyophora cinnabarina.Cur. Sci. 92: 1219-1220.

Abrar, S., Swapna, S. and Krishnappa, M. 2012. Development and morphology of Lysurus cruciatus - an addition to the Indian mycobiota. Mycotaxon 122: $271-282$.

Acharya, K., Pradhan, P., Chakraborty, N. et al. 2010. Two new species of Lysurus Fr.- addition to the Macrofungi of West Bengal. J. Bot. Soc. Bengal 64: 175-178.

Agarwal, R.K., Gupta, K.K., Kumar, S. and Seth, P.K. 1984. Gasteromycetes of Himachal Pradesh. Indian Phytopath. 27: 45-48.

Ahmad, S. 1940. Higher fungi of the Punjab Plains-II. The Gasteromycetes. J. Ind. Bot. Soc. 18: 169-177.

Cabral, T.S., Marinho, P., Goto, B.T. and Baseia, I.G. 2012. Abrachium, a new genus in the Clathraceae, and Itajahya reassessed. Mycotaxon 119: 419-429.

Caffot, M.L.H., Hosaka, K., Dominguez, L.S. and Urcelay, C. 2018. Molecular and morphological data validate the new combination of Lysurus sphaerocephalum from Argentina, with some additional records on Phallales (Agaricomycetes). Mycologia 110: 419433.

Dai, Y.C., Yang, Z.L., Wen, H.A. et al. 2010. A revised checklist of edible fungi in China. Mycosystema 29: $1-21$. 
Das, K., Singh, S. and Calonge, F. 2007. Gasteromycetes of Western Ghats, India: I. A new form of Phallus indusiatus. Bol. Soc. Micol. Madrid 31: 135-138.

Dash, P., Sahu, D., Sahoo, S. and Das, R. 2010. Phallus indusiatus Vent. \& Pers. (Basidiomycetes) - a new generic record for Eastern Ghats of India. J. Threat. Taxa 2: 1096-1098.

Dring, D.M. 1964. Gasteromycetes of West Tropical Africa. Mycol. Pap. 98: 1-60.

Dutta, A.K., Chakraborty, N., Pradhan, P. and Acharya, K. 2012. Phallales of West Bengal, India. II. Phallaceae: Phallus and Mutinus. Researcher 4: 2125.

Gogoi, G. and Parkash, V. 2014. Some new records of stinkhorns (Phallaceae) from Hollongapar Gibbon Wildlife Sanctuary, Assam, India. J. Mycol.: http://dx.doi.org/10.1155/2014/490847

Gogoi, G. and Parkash, V. 2015. Lysurus habungianus sp. nov. (Phallaceae) - A new stinkhorn fungus from India. Cur. Res. Environ. Appl. Mycol. 5: 248-255.

Greeshma, A.A., Sridhar, K.R., Pavithra, M. and Ghate, S.D. 2016. Impact of fire on the macrofungal diversity of scrub jungles of Southwest India. Mycology 7: 1528.

Index Fungorum. 2019: http://www.indexfungorum.org/ names/Names.asp

Karun, N.C. and Sridhar, K.R. 2014. A preliminary study on macrofungal diversity in an arboretum and three plantations of the southwest coast of India. Cur. Res. Environ. Appl. Mycol. 4: 173-187.

Karun, N.C. and Sridhar, K.R. 2016. Spatial and temporal diversity of macrofungi in the Western Ghat forests of India. Appl. Ecol. Environ. Res. 14: 1-21.

Karun, N.C., Bhagya, B. and Sridhar, K.R. 2018. Biodiversity of macrofungi in Yenepoya Campus, Southwest India. Microb. Biosys. 3: 1-11.

Kour, H., Yangdol, R., Kumar, S. and Sharma, Y.P. 2016. Three species of Phallus (Basidiomycota: Agaicomycetes: Phallaceae) from Jammu \& Kashmir, India. J. Threat. Taxa 8: 8403-8409.

Li, H., Ma, X., Mortimer et al. 2016. Phallus haitangensis, a new species of stinkhorn from Yunnan Province, China. Phytotaxa 280: 116-128.
Li, H., Mortimer, P.E., Karunarathna, S.C. et al. 2014. New species of Phallus from a subtropical forest in Xishuangbanna, China. Phytotaxa 163: 91-103.

Lin, C., Lin, R. and Lin, X. 2011. Study on the development of the comprehensive utilization about the Dictyophora resource. Edible Fungi of China 30: 811.

Medeiros, G.S., Rodrigues, A.C.M., Cruz, R.H.S.F. et al. 2017. Phallus fluminensis, a new species of stinkhorn from the Brazilian Atlantic rainforest. Studies in Fungi 2: 191-198.

Mohanan, C. 2011. Macrofungi of Kerala. Kerala Forest Research Institute, Kerala, India.

Narasimhan, M.J. 1932. The Phalloideae of Mysore. J. Ind. Bot. Soc. 11:248-254.

Patil, M.S. 1978. Some fleshy fungi from Maharashtra-III. Indian Phytopath. 31:32-35.

Song, B., Li, T., Li, T. et al. 2018. Phallus fuscoechinovolvatus (Phallaceae, Basidiomycota), a new species with a dark spinose volva from southern China. Phytotaxa 334: 19-27.

Soosairaj, S., Raja, P., Kala, A. and Kalainger, R.P. 2012. Survey of macrofungi from a few, District of Tamil Nadu. The Bioscan 7: 669-671.

Sridhar, K.R. and Karun, N.C. 2013. On the basket stinkhorn mushroom Phallus merulinus (Phallaceae) in Mangalore, Karnataka, India. J. Threat. Taxa 5: 3985-3988.

Swapna, S., Abrar, S., Manoharachary, C. and Krishnappa, M. 2010. Development and morphology of Clathrus delicatus (Phallomycetidae, Phallaceae) from India. Mycotaxon 114: 319-328.

Tewaria, V.P. and Khare, K.B. 1968. Two interesting Phalloids from Uttar Pradesh. Indian Phytopath. 21:374-378.

Trierveiler-Pereira, L., Meijer, A.A.R. and Silveira, R.M.B. 2019. Phallales (Agaricomycetes, Fungi) from Southern Brazil. Studies in Fungi 4: 162-184. 